第 33 回獣医疫学会学術集会

ワークショップ“獣医疫学の実践教育”

\title{
大学における実践疫学教育の試み
}

\author{
蒔田浩平* \\ 酪農学園大学 獣医学群獣医学類獣医疫学ユニット

\section{The Efforts on Practical Education of Epidemiology in a University}

\author{
Kohei MAKITA*
}

Veterinary Epidemiology Unit, Department of Veterinary Medicine,

School of Veterinary Medicine, Rakuno Gakuen University, 582 Bunkyodai Midorimachi, Ebetsu, Japan

\begin{abstract}
Summary
In Japan, following the recent outbreaks of emerging/ re-emerging zoonoses and trans-boundary diseases, the importance of epidemiology in application to control such disease is increasingly recognized. Although far belated from the other countries, veterinary epidemiology education started in 2006 and the first independent veterinary epidemiology unit in Japan was established in 2010 in Rakuno Gakuen University. We introduces the education system associated with veterinary epidemiology in the university. The Veterinary Epidemiology Unit aims for problem-oriented approach and internationalization and deals with wide range of problems inside and outside Japan, frequently using trans-disciplinary approach such as One Health. In order to start applied veterinary epidemiology education in Japanese universities, veterinary epidemiology experts should strengthen their networks to provide good back-stopping of the newly assigned researchers. It is also important to appeal for the establishment of regulatory science funds for epidemiology attached with the capacity development of veterinary graduate students.
\end{abstract}

\section{1. はじめに}

国内外で新興・再興人獣共通感染症や越境性疾病の発生 が見られる中, 我が国ではそれら感染症対策への疫学の応 用の重要性が改めて認識されてきている。

獣医疫学は, 家畜衛生, 獣医公衆衛生分野および環境分 野において，その応用が直接政策の決定に繋がる可能性が 高いことから，これまで主に国家または独立行政法人の研 究組織において研究・人材育成されてきた。しかし近年こ れに加えて各獣医系大学でもコアカリキュラムにおける疫 学の採用を受けて, あるいはそれ以前から必要性の認識が 高まったことにより, 獣医疫学教育が始まっている。本稿

連絡先：蒔田浩平*

酪農学園大学獣医学群獣医学類衛生環境教育分野

獣医疫学ユニット

干069-8501 北海道江別市文京台緑町 582 番地

Tel : 011-388-4761; Fax : 011-388-4761

E-mail : kmakita@rakuno.ac.jp
では, 全国の獣医系大学に先駆けて 2010 年に独立の獣医 疫学研究ユニットが開設された酪農学園大学における獣医 疫学実践教育の歴史と現在の取り組みについて紹介する。

\section{2. 酪農学園大学における獣医疫学教育の導入}

酪農学園大学では逸早く獣医疫学の重要性を認識し, 2006 年より「総合獣医臨床学」の一部として家畜診療に おける獣医臨床疫学教育を獣医学科 5 年次対象で開講し た。この頃から及川教授, 中田教授により獣医疫学教育が 始まった。また 2004 年に着任された田村獣医公衆衛生学 教授 (当時, 現食品衛生学教授) により, 疫学教育は獣医 公衆衛生学総論の中で徐々に充実して行った。2010 年 4 月には大講座制である衛生環境教育分野の一部として獣医 疫学ユニットが開設された。

\section{2012 年度に酪農学園大学で行われている 学部生への獣医疫学教育}

獣医学科の学生が最初に疫学に触れるのは, 3 年次の獣 
医公衆衛生学総論である。ここでは 8 時限を用いて人の疫 学について広く学ぶ。用いられている教科書は「やさしい 疫学 第二版」(日本疫学会, 2010) である。

2011 年度に始まった「獣医疫学」は通年で獣医学科 4 年次に開講されている。講義は基本的に「獣医疫学第二 版」（獣医疫学会, 2011）に沿って実施されている。この 獣医疫学の教科書はコアカリキュラム対応であり, 基本的 に本書さえ教えれば国家試験対策には十分である。本書に は，コアカリキュラムでは必須単元として指定されていな いが関係各方面で非常に重要な経済学に関する項目なども 含まれている。獣医疫学の講義では, コアカリキュラム必 須項目に該当しない獣医経済学, 参加型疫学についても教 えており, 教科書には含まれない GIS の応用や精神保健 学との連携例についても教えている。学生には「統計アレ ルギー」を起こさせないよう, 筆者のアフリカでの研究ス ライドや, 身近な事柄から例を持ち出して講義を実施して いる。講義中に, 統計ソフト ‘R’ を用いて実際にデモで 解析やグラフ化も実施し, 目で見て実感させる講義も実施 している。また, サーベイランスと産業動物臨床疫学につ いては, 外部講師を呼び, 疫学が応用されている現場の生 の声を学生に伝えている。

臨床獣医学の知識も増えた獣医学科 5 年次には, 及川教 授, 中田教授（ハードヘルス・ユニット）担当の「ハード ヘルス学」が開講されている。ハードヘルス学では牛群に おける疾病予防と衛生管理について学ぶ。また座学のハー ドヘルス学で得た知識を深める内容の「予防衛生学実習」 も開講されており, 家畜保健衛生所からの外部講師を呼び, 机上防疫演習を実施している他, 生産/疾病デー夕, 牛群 モニター結果の分析と判読方法について教えている。群管 理は養豚や養鷄でも重要であるが，ハードヘルス・ユニッ 卜は「生産管理学」の講義の中で, 養豚における生産管理, 生産疫学, 経営およびアニマルウェルフェアについて教え ている。

獣医疫学の実習科目としては, 獣医学科 5 年次に「獣医 疫学実習」が開講されている。本実習では, 人獣共通感染 症学の教員が診断系の教育を担当し, 疫学教員が 3 回に渡 りコンピュータを用いた実習を担当している。内容として は, Microsoft エクセル， R を用いた疫学指標の計算とオッ ズ比およびその信頼区間の算出を, 疾病の机上発生演習の 中で班ごとに実施している。本演習では, 分析だけでなく, 卒業を一年後に控えた学生に, 北海道庁職員というロール （役割）を与え，保健所長というロールを演じる教官に報 告させるロール・プレイも用いている。また本実習では, 実践疫学では非常に有用なデータベース作りを, Microsoft アクセスを用いて教えている。本年度の題材は, 家畜診療 所と伴侶動物の動物病院における診療データベースの作成
であった。

\section{4. 獣医疫学ユニットにおける学部生専門教育}

学部生の専門教育として, 本学の場合は 4 年次後期から 研究ユニットに所属し研究を実施する。当ユニットには, 2010 年度に 2 名, 2011 年度に 4 名, 2012 年度に 4 名入室 し, 現在合計 10 名の学生が所属している。本ユニットの 顕著な特徵は, 英語環境が挙げられる。学生は廊下から一 歩室内に入ると, 全ての会話を英語でしなければならない。 この理由は, 疫学は集団を対象とする学問であり, 疫学者 が勤務する職場の多くでは, 他国や国際機関とのコミュニ ケーションを通常業務として要求されるからである。最初 の 2 年間は, 学生は恥ずかしさと意義の理解不足から, 私 がいないところでは日本語で会話していた。しかし環境と いうものは面白いもので, ユニット内の学年が 6 年生まで 揃った今は英語環境が当たり前になり, 学生の研究部屋か らは毎日英語の元談と笑い声が聞こえてくる。

ユニット全体でのミーティングは週一回月曜日で, 内容 は研究発表とジャーナルクラブ（論文紹介）である。また, この機会に全員から前の週の活動内容とその週予定してい る作業が報告される。

また毎週火曜日は統計学実習を行っている。進度が違う ので, 4 年生と $5 \cdot 6$ 年生は分けて別室で同時に行う。教 科書には「R Book」(Crawley, 2007) を使用しており, Arc GIS のヘルプ中のセルフ・ラーニング機能を用いた GIS 研 修も実施している。統計学の内容は, R の使用方法, Rの グラフィックス, 数学, 古典的統計, 回帰分析, ANOVA, ANCOVA, GLM，生存分析などである。

夏休みには，2 週間の集中リスク評価コースを実施し， ここでベイズ統計について学ぶ。この研修コースは本年度 から始まったものである。研修には外部からの参加者も受 け入れており, 本年度は国際家畜研究所 (ILRI) のプロジェ クトで活動する 4 名, 帯広畜産大学大学院から 1 名, 北海 道大学大学院医学研究科加 3 名, 食品安全委員会から 1 名, 農林水産省動物医薬品検査所から 1 名の参加があった。 疫学の実践教育については, 学部生各々与えられたテー マの研究を通して実施する。この中で, 国内の研究を実施 する者も他の室員の発表からグローバルな問題について学 ぶ。研究テーマによっては微生物学的または生化学的診断 手技を必要とされるが, この場合学生は共同研究者からそ のような技術を学び, 実験している。研究ユニット所属生 への教育目標は, (1)問題解決能力の養成, (2)英語でのコミュ ニケーション・実務能力の養成, (3)ディスカッションにお ける積極的参加姿勢の醸成そして(4)応用統計・疫学研究に 対応できる基礎学力の養成である。しかしコミュニケー ションや統計学など, 個人の向き, 不向きもあるため, 個 
表 1 獣医疫学ユニットでこれまでに実施されている研究内容

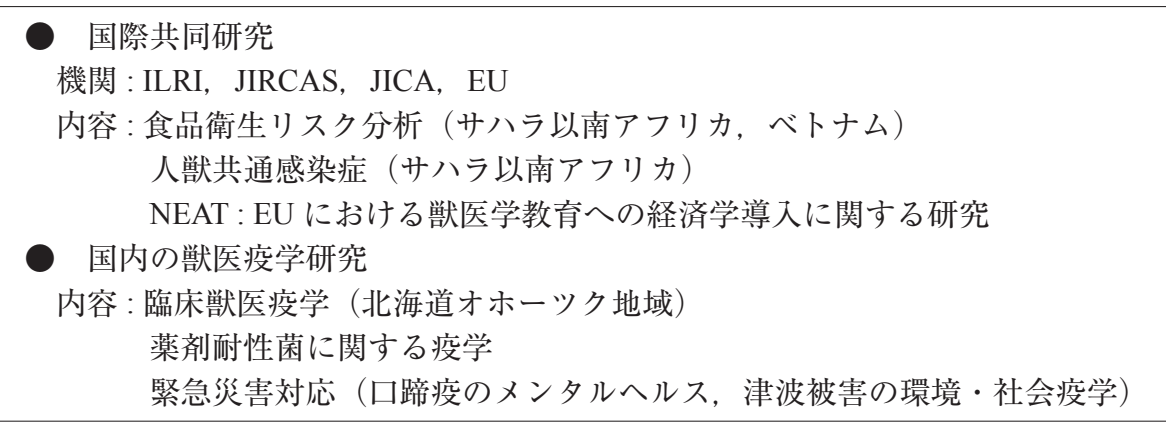

性と特性に合わせた指導も重要視している。

\section{5. 獣医疫学ユニットの方向性}

獣医疫学ユニットの目指す方向性は, (1)国際性と(2)問題 中心アプローチ, の二つに集約される。この問題中心アプ ローチは, 蒔田が留学先のエデインバラ大学で学んだ哲学 である。自分の専門は確保しつつも柔軟かつ大胆に野外で の問題の本質に迫る指導教官 Sue Welburn 教授の動きに影 響を受けている。「問題」とするのは獣医学, 獣医公衆衛 生学が重なる範囲の問題であり, 中心的なテーマは, 発展 途上国の食品媒介性人獣共通感染症の持続可能な疾病制 御と貧困削減である。アプローチとしては, One Health, Trans-disciplinary approach, EcoHealth などの分野横断への 挑戦を常に念頭に置いている。また国内の重要課題にも, 数は絞っても範囲は広く挑戦していきたい。専門は「疫学」 であり，「リスク」に興味がある。また疾病制御によりど のようにリスクや疾病状況が変化するか，どのように負の 影響を作らずにそれらを制御するかにも興味がある。現在 までに当ユニットで行われている研究は表 1 のとおりであ る。2010年の口蹄疫と 2011 年の東日本大震災の発生もあっ て,さらに幅が拡がっている。

表 1 中の NEAT の正式名は, Networking to enhance the use of economics in animal health education, policy making and research in Europe and beyond である。代表者は王立獣医科 大学 (ロンドン大学) の経済学者 Jonathan Rushton で, 酪 農学園大学の役割は, 日本の獣医学教育における獸医経済 学教育の実施状況の調查と, EU 圈外の視点で見た NEAT で作成する教材の質と普及可能性の評価である。

\section{6. 大学の獣医疫学実践教育の課題}

我が国の大学で獣医疫学実践教育を始めるに当たっての 課題としては，(1)実習をどのように取り入れるか，(2国内 でこれまで獣医疫学教育がなかった状況の中で, 各大学で どのように担当教員を確保するか, が緊急のものとして挙
げられる。これらの課題に対応するためには, 新しく疫学 を担当する教員に対して, 国内の医・獣医疫学者が技術的 サポートを行わなければならない。このためにはまず，国 内獣医疫学ネットワークの強化が重要であると考えられ る。

また研究レベルで大学での疫学実践を進めていくには, 農林水産省, 厚生労働省, 食品安全委員会および各自治体 など公的機関のご理解・ご協力なしには達成できない。な ぜならば, 疫学は他の獣医学術分野とは異なり, 新しい科 学技術を創設することが主な目標ではなく，集団における 疾病低減や公共福祉の向上が目標であるからである。具体 的には, 欧米のような, 重要テーマ解決のための, 大学院 生の授業料や生活費を組み入れた疫学研究資金の充実が挙 げられる。疫学の実践は, 応用統計, 異文化連携, また獣 医師免許を持つ者による研究の必要性から, やはり大学院 レベルで行われることが望ましい。このような枠組みはレ ギュラトリー・サイエンスとしてすでに存在しているが, より明確で獣医学生にとって大学院での疫学研究が進路の 選択肢の一つになるようさらに整備されるべきであると考 える。

また国際保健疫学や国際獣医疫学についても, 大学院で の人材育成と抱合せの One Health など $\mathrm{OIE} ・ \mathrm{FAO} \cdot \mathrm{WHO}$ が重点課題とするような世界の潮流に沿った資金が充実さ れると，一層獣医疫学分野の国際化が進むと思われる。い ずれにせよ筆者はまだ駆け出しであるので，遥か先に我が 国の大学疫学教育の進展に想いを巡らしつつも, 足元を見 ながら少しずつ確実に実績を積み上げていきたい。

\section{参考文献}

獣医疫学会 : 獣医疫学一基礎から応用まで一. 第二版. 近 代出版, 2011.

日本疫学会: はじめて学ぶやさしい疫学〜疫学への招待

． 改訂第 2 版. 南江堂, 2010.

Crawley, M.J. : The R Book. John Wiley \& Sons Ltd., 2007. 